\title{
Prochristianella mattisi sp. n. (Trypanorhyncha: Eutetrarhynchidae) from the wedgenose skate, Dipturus whitleyi (Rajiformes: Rajidae), from Tasmania (Australia)
}

\author{
Bjoern C. Schaeffner and Ian Beveridge
}

Department of Veterinary Science, The University of Melbourne, Veterinary Clinical Centre, Werribee, Victoria, Australia

\begin{abstract}
A new species of Prochristianella Dollfus, 1946 is described from the spiral intestine of the wedgenose skate, Dipturus whitleyi (Iredale) (Rajiformes: Rajidae), off the north-western coast of Tasmania (Australia). Prochristianella mattisi sp. n. is characterised by an acraspedote scolex, two oval bothria, elongate, bent bulbs, a retractor muscle inserting at the base of each bulb and the presence of gland-cells within the bulbs and prebulbar organs. The tentacular armature is typical heteroacanthous, heteromorphous, with a characteristic basal oncotaxy and a metabasal armature with hooks first increasing and then decreasing in size along each principle row. It can be differentiated from other species of Prochristianella by a combination of morphological characters, such as the metabasal tentacular armature with eight hooks per principle row, a unique basal armature without enlarged hooks on the basal swelling and genital pores slightly posterior to the mid-line of the segment. The description of $P$. mattisi sp. n. increases the number of known species within Prochristianella to 20, eight of which occur in Australian waters. A key for the identification to species within Prochristianella is provided.
\end{abstract}

Keywords: tapeworms, Cestoda, taxonomy, parasites, Prochristianella, rays, identification key

The eutetrarhynchid genus Prochristianella Dollfus, 1946 accommodates species with a characteristic basal tentacular armature and a metabasal armature with an initial gradual increase of hook sizes followed by a gradual decrease along the principle rows (Dollfus 1946). Beveridge et al. (2004) provided the most recent generic diagnosis. However, a uniform diagnosis proved problematic, because intermediate forms now exist exhibiting morphological characteristics of the closely related genera Dollfusiella Campbell et Beveridge, 1994 and Eutetrarhynchus Pintner, 1913 (see Schaeffner and Beveridge 2012). The first key for the morphological identification of species within Prochristianella was compiled by Palm (2004), including 13 species. Since then, several species have been added. Friggens and Duszynski (2005) described Prochristianella multidum Friggens et Duszynski, 2005 from Mexico, while Beveridge and Justine (2010) added two species from New Caledonia, $P$. aciculata Beveridge et Justine, 2010 and $P$. omunae Beveridge et Justine, 2010.

In the most recent study, Schaeffner and Beveridge (2012) described four additional species of Prochristianella from Australia and Borneo. These authors also synonymised $P$. macracantha Palm, 2004 with $P$. butlerae Beveridge, 1990, due to apparent morphological similarities, and provided new host and locality records for three additional species. To date, 19 species of Prochristianella are considered valid, namely: $P$. aciculata; P. butlerae; P. cairae Schaeffner et Beveridge, 2012; P. clarkeae Beveridge, 1990; P. fragilis Heinz et Dailey, 1974; P. glabra (Dollfus, 1969); P. heteracantha Dailey et Carvajal, 1976; P. hispida (Linton, 1890); P. jensenae Schaeffner et Beveridge, 2012; P. kostadinovae Schaeffner et Beveridge, 2012; P. minima Heinz et Dailey, 1974; P. mooreae Beveridge, 1990; P. multidum; P. odonoghuei Beveridge, 1990; P. omunae; P. papillifer (Poyarkoff, 1909) (type-species); P. scholzi Schaeffner et Beveridge, 2012; P. thalassia (Kovacs et Schmidt, 1980) and P. tumidula (Linton, 1890).

The present material represents a new species of Prochristianella, increasing the number of valid species within the genus to 20. Prochristianella, thus, represents one of the most species-rich genera within the Eutetrarhynchidae. For this reason, a key for the species of Prochristianella is provided.

\section{MATERIALS AND METHODS}

Specimens of this study were obtained from the spiral intestine of the wedgenose skate, Dipturus whitleyi (Iredale), examined from the Bass Strait off Stanley, Tasmania, Australia. Cestodes were fixed in $10 \%$ formalin for morphological observation and later placed in $70 \%$ ethanol. Selected specimens 
were processed as described by Schaeffner et al. (2011). Line drawings of mounted specimens were made using an Olympus BH2 microscope with a drawing tube and Nomarski interference contrast. The terminology of morphological characteristics follows Dollfus (1942) and Campbell and Beveridge (1994). The attachment organs are referred to as bothria following Hyman (1951), Caira et al. (1999) and Jones et al. (2004). Microthrix terminology follows Chervy (2009). Measurements are in micrometres $(\mu \mathrm{m})$, unless otherwise indicated, and are given as the range followed in parentheses by the mean, standard deviation and the number of features measured. Vitelline follicles are shown on the lateral margins of segments only, unless otherwise indicated. Three specimens were selected for scanning electron microscopy (SEM) and processed as described in Schaeffner et al. (2011). Scanning electron micrographs were taken using a Hitachi S-570 scanning electron microscope (Hitachi Ltd.). Type-specimens mounted on microscope slides have been deposited in the helminthological collections of the South Australian Museum, Adelaide, Australia (SAM), and the United States National Parasite Collection, Beltsville, Maryland, USA (USNPC). Host classification follows Naylor et al. (2012).

\section{RESULTS}

\section{Prochristianella mattisi sp. n.}

Figs. 1-7

Description. Based on 11 whole-mounts, two specimens in glycerol, three specimens used for SEM. Mature cestodes 4.2-5.5 (4.7 $\pm 0.7 ; \mathrm{n}=3) \mathrm{mm}$ long, with $6-11(9 \pm 3 ; n=3)$ segments in mature strobilae; strobila with $5-9(7 \pm 2 ; \mathrm{n}=3)$ immature segments and $1-2$ $(1 ; \mathrm{n}=3)$ mature segments; gravid segments not present. Scolex acraspedote (Figs. 1, 2), 1 500-2030 (1637 \pm 168 ; $\mathrm{n}=9$ ) long; maximum width at level of pars bothrialis, $430-530(487 \pm 36 ; \mathrm{n}=6)$ wide; pars bothrialis $360-420$ $(395 \pm 20 ; n=10)$ long; bothria two in number, oval, $350-450(390 \pm 37 ; \mathrm{n}=10)$ long by $350-420(397 \pm 24$; $\mathrm{n}=10$ ) wide, with free posterior margins, prominent posterior notch absent, V-shaped ridge seen in SEM specimens only; distal bothrial surface covered with columnar spinitriches; proximal bothrial surface covered with acicular filitriches; bothrial pits absent; pars vaginalis longer than pars bothrialis, 870-1220 (972 \pm 109 ; $\mathrm{n}=10$ ) long; tentacle sheaths thin, sinuous to irregularly coiled, 15-20 $(19 \pm 2 ; \mathrm{n}=10)$ in diameter; pars bulbosa $590-810(654 \pm 70 ; n=10)$ long by $290-410(347 \pm 43$; $\mathrm{n}=11)$ wide; prebulbar organs present, small; bulbs elongate (Fig. 3), bent, thick-walled, 600-760 (649 \pm 53 ; $\mathrm{n}=22)$ long by $100-130(117 \pm 10 ; \mathrm{n}=22)$ wide, in some specimens reach to pars proliferans scolecis; bulb width : length ratio $1.0: 4.6-7.5(5.6 \pm 0.7 ; \mathrm{n}=22)$; retractor muscle broad (Fig. 3), originates at base of bulb; gland-cells present, in posterior third to mid-region of bulb (Fig. 3); pars post-bulbosa absent; scolex ratio (pars bothrialis : pars vaginalis : pars bulbosa) $1.0: 2.1-2.9$ : $1.4-1.9(1.0: 2.5 \pm 0.2: 1.6 \pm 0.2 ; \mathrm{n}=9)$.

Fully everted tentacle $940(\mathrm{n}=1)$ long; tentacle diameter $28-33(30 \pm 2 ; n=6)$ at base, $23-28(25 \pm 2 ; n=6)$ in metabasal region, $20-23(21 \pm 1 ; \mathrm{n}=6)$ in distal re- gion. Armature heteroacanthous, heteromorphous; hooks hollow, in ascending half spiral rows (Figs. 5, 6). Hook files begin on antibothrial surface of tentacle (Fig. 5), terminate on bothrial surface (Fig. 6); 8 hooks per principle row; hook files 1 and 1' slightly spaced (Fig. 5). Hooks 1 (1') uncinate, 10-13 (11 $\pm 1 ; \mathrm{n}=15)$ long, base 6-8 $(7 ; \mathrm{n}=15)$ long; hooks 2 (2') uncinate, slightly larger, $10-14(12 \pm 1 ; n=9)$ long, base 5-8 (7 $\pm 1 ; n=19)$ long; hooks 3 (3') falcate, larger, $12-15(13 \pm 1 ; \mathrm{n}=15)$ long, base narrower, 4-5 (4; $n=15)$ long; hooks 4 (4') falcate, smaller, 6-9 $(8 \pm 1 ; \mathrm{n}=15)$ long, base 3-4 $(4 \pm 1 ; \mathrm{n}=15)$ long; hooks 5 (5') falcate, larger, 11-14 (12 $\pm 1 ; \mathrm{n}=15)$ long, base $4-5(4 ; \mathrm{n}=15)$ long; hooks $6\left(6^{\prime}\right)-8\left(8^{\prime}\right)$ spiniform, of similar size, $6-7(6 ; n=30)$ long, base $1-3(2 \pm 1$; $\mathrm{n}=30$ ) long.

Distinctive basal armature present (Fig. 7); basal hooks on external surface uncinate, 4-7 (6 $\pm 1 ; \mathrm{n}=5)$ long, base 2-4 (3 $\pm 1 ; n=5)$ long; basal hooks on bothrial and antibothrial surfaces falcate, greatly enlarged, 8-12 (9 \pm 1 ; $\mathrm{n}=15)$ long, base $1-3(2 ; \mathrm{n}=15)$ long; patch devoid of hooks on external surface; hooks anterior to patch falcate, small, 3-4 $(3 ; \mathrm{n}=11)$ long, base $c .1(\mathrm{n}=11)$ long; basal swelling weakly developed, with $c$. 11 rows of billhooks (Fig. 7); billhooks of almost similar size (Fig. 7), 3-5 $(4 \pm 1 ; n=20)$ long, base $c .1(n=20)$ long; billhooks become uncinate towards bothrial surface anterior to hook row 11 on basal swelling (Fig. 7), 2-3 (2; n = 7) long, base $2-3(2 ; n=7)$ long; hooks of first principle rows uncinate, of almost similar size (Fig. 7), 5-6 (6 $\pm 1 ; n=6)$ long, base 4-5 (4 $\pm 1 ; \mathrm{n}=6)$ long.

Segments acraspedote; immature segments 30-50 $(35 \pm 9 ; \mathrm{n}=5)$ long by $230-320(262 \pm 35 ; \mathrm{n}=5)$ wide; terminal mature segments 1390-1430 (1410 $\pm 28 ; n=2)$ long by $230-310(270 \pm 56 ; \mathrm{n}=2)$ wide. Genital pores slightly posterior to mid-line of segment (Fig. 4); pore inconspicuous; cirrus sac ovoid (Fig. 4), $88(\mathrm{n}=1)$ long by $113(\mathrm{n}=1)$ wide; cirrus unarmed; internal and external seminal vesicles absent. Vas deferens not observed. Testes arranged in two columns, in 1-2 layers, exclusively preovarian, absent in region of cirrus sac (Fig. 4), 58-68 $(59 \pm 3 ; \mathrm{n}=10)$ long by $33-38(36 \pm 2 ; \mathrm{n}=10)$ wide; total number of testes $58-71(64 \pm 7 ; \mathrm{n}=3)$, with $38-41$ $(39 \pm 2 ; \mathrm{n}=3)$ preporal, and $20-30(25 \pm 5 ; \mathrm{n}=3)$ postporal. Vagina enters genital atrium posterior to cirrus-sac (Fig. 4); course of vagina not observed; seminal receptacle absent. Ovary at posterior margin of segment, bilobed in dorsoventral view; ovarian lobes 75-78 $(\mathrm{n}=2)$ long by $35-40(n=2)$ wide. Mehlis' gland between posterior parts of ovarian lobes; c. $55(\mathrm{n}=1)$ in diameter. Vitelline follicles small, circumcortical, $10-15(13 \pm 2 ; n=10)$ in diameter. Uterus median, tubular, simple, extending between rows of testes to anterior extremity of segment; uterine pore absent.

Type and only host: Dipturus whitleyi (Iredale) (Rajiformes: Rajidae). 
1

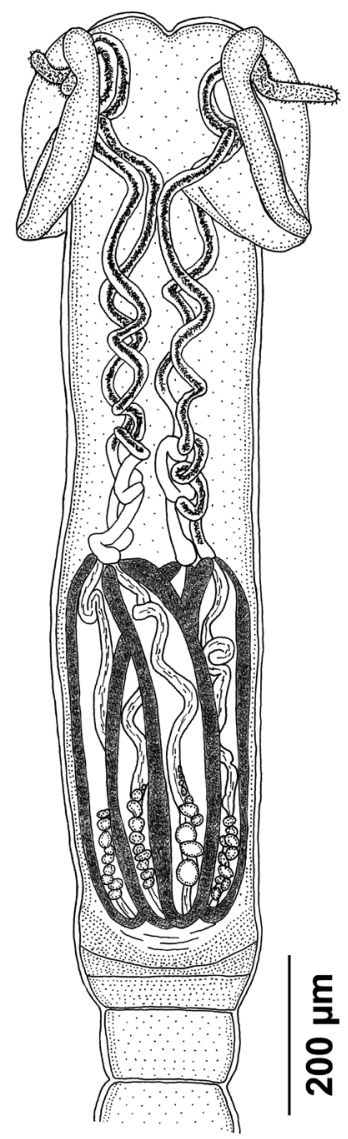

2

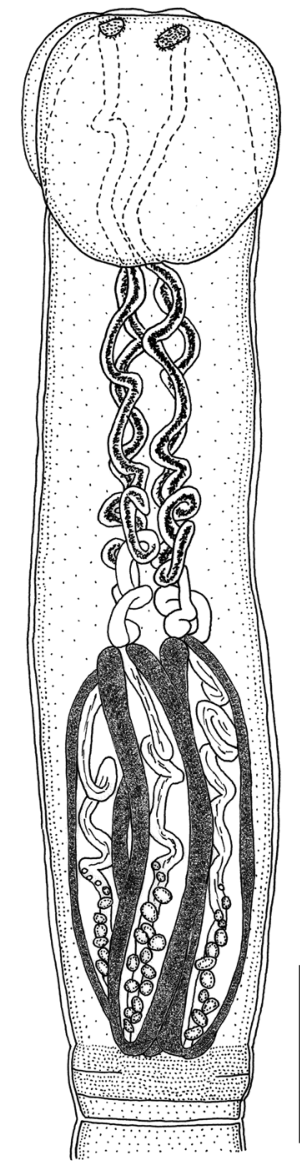

3

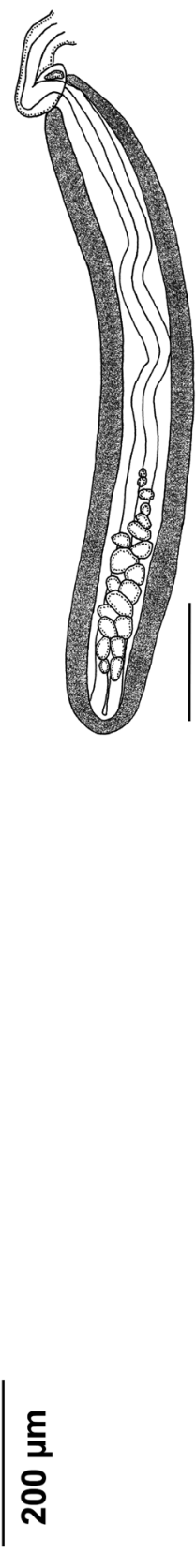

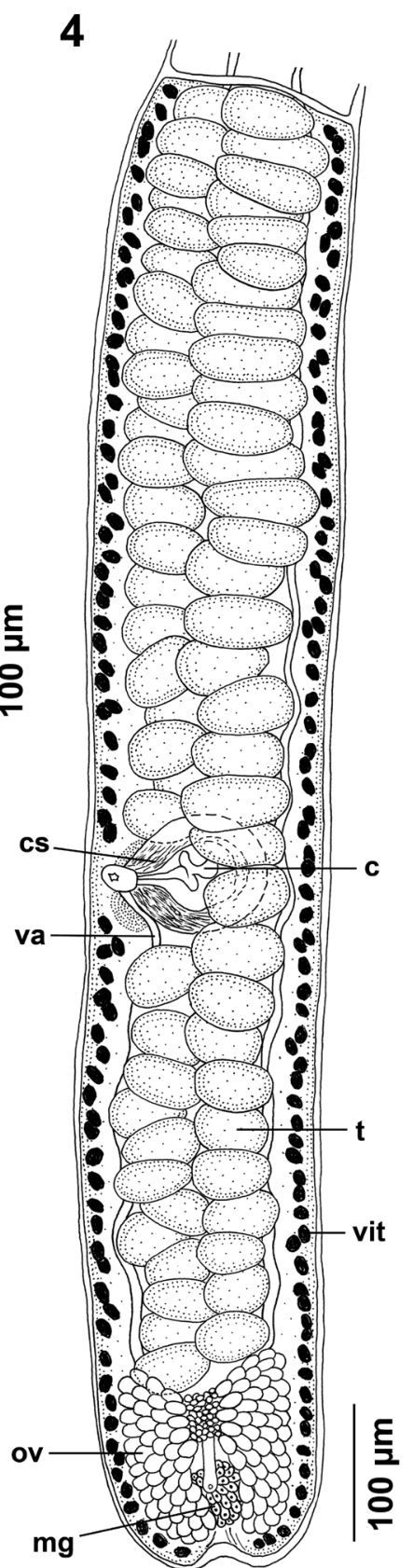

Figs. 1-4. Line drawings of Prochristianella mattisi sp. n. Fig. 1. Scolex in lateral view. Fig. 2. Scolex in dorso-ventral view. Fig. 3. Bulb. Fig. 4. Mature segment. Abbreviations: c - cirrus; cs - cirrus-sac; mg - Mehlis' gland; ov - ovary; $t$ - testis; va - vagina; vit - vitelline follicle.

Type loc a lity: Bass Strait off Stanley, Tasmania, Australia $\left(40^{\circ} 37^{\prime} \mathrm{S}, 17^{\circ} 43^{\prime} \mathrm{E}\right)$.

Additional localities: None.

Site of infection: Spiral intestine.

Specimens deposited: Holotype in SAM (AHC 35627); paratypes in SAM (AHC 35628-31) and USNPC (106132-33).

E ty mology: This species is dedicated to Tom E. Mattis, who passed away at the end of 2012, for his efforts in elucidating the life-cycles of trypanorhynchs, many productive discussions and his lively interest in species of the genus Prochristianella.
Remarks. The species described above belongs to the eutetrarhynchid genus Prochristianella, due to its acraspedote, slender scolex, two oval bothria, bulbs with gland-cells, a retractor muscle inserting at the base of the bulb and the presence of prebulbar organs. The tentacular armature shows a basal swelling, with a characteristic basal armature and a heteroacanthous metabasal region, with hooks gradually increasing and then decreasing in size along each principle row. However, the present specimens show the gradation of hooks along each principle row in the metabasal armature being interrupted by 


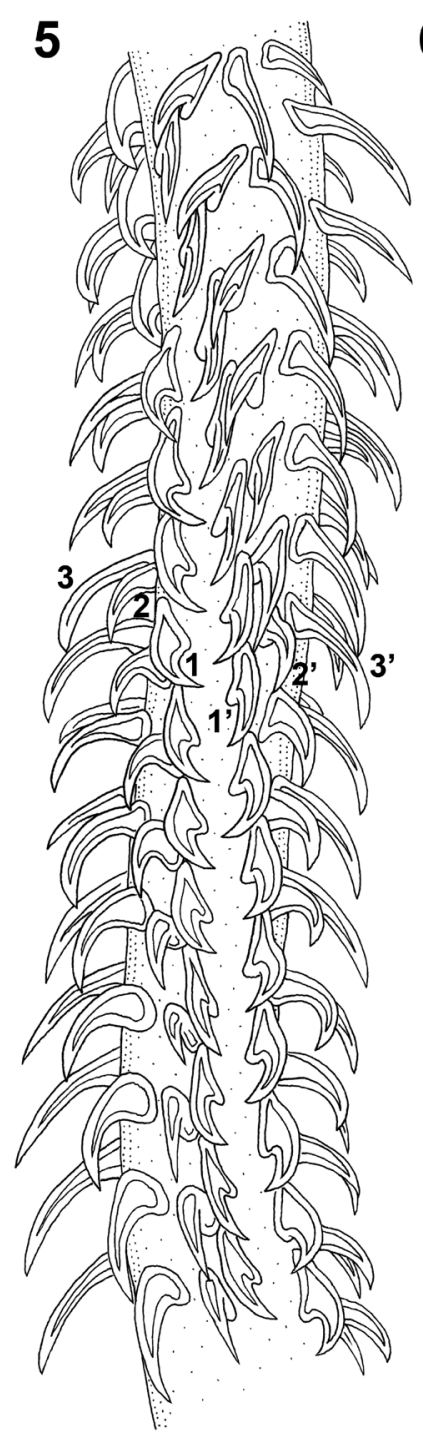

6

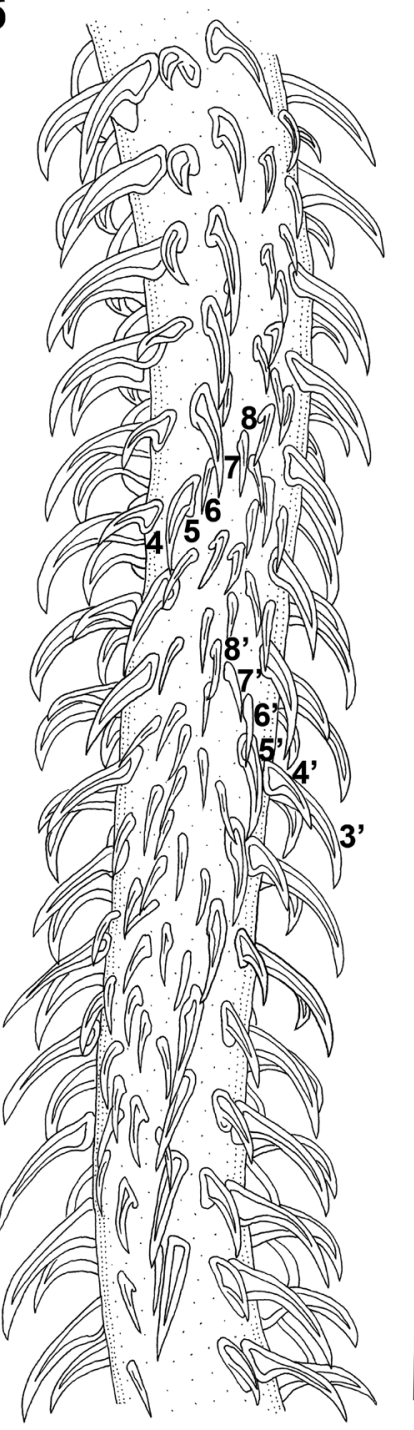

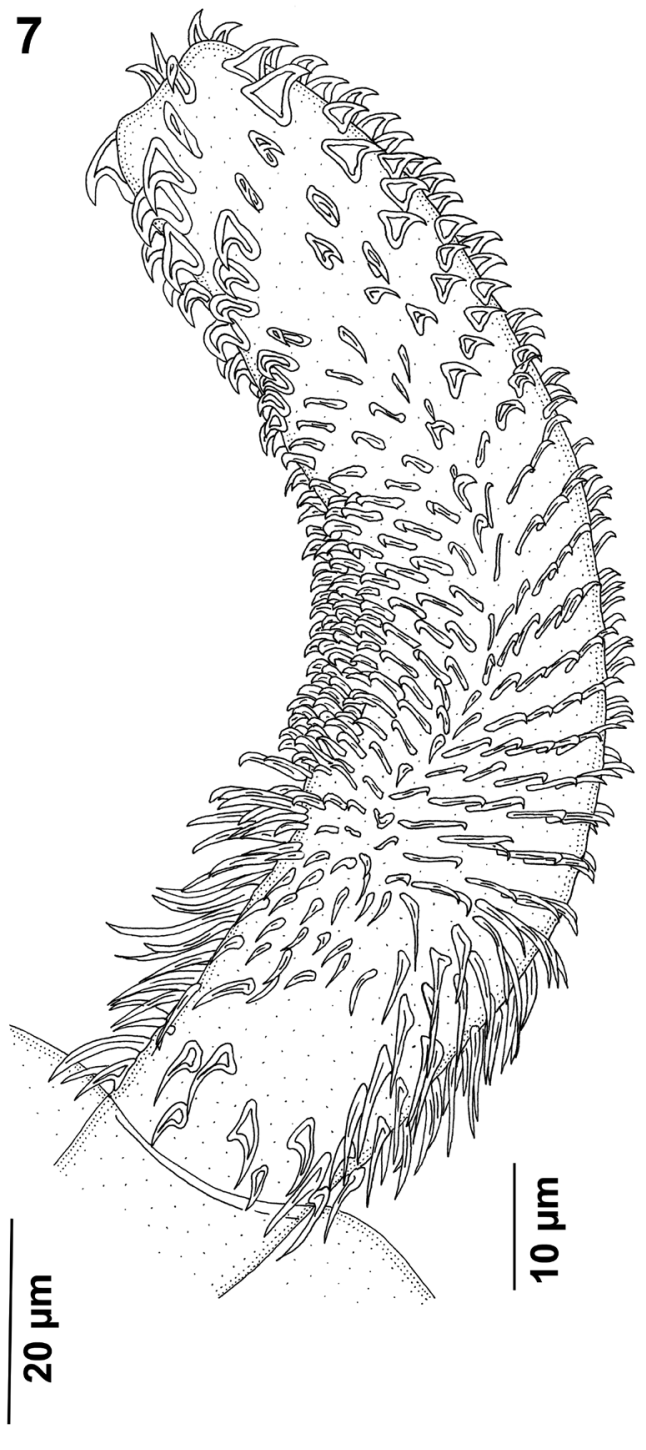

Figs. 5-7. Line drawings of tentacular armature of Prochristianella mattisi sp. n. Fig. 5. Metabasal armature, antibothrial surface. Fig. 6. Metabasal armature, bothrial surface. Note: opposing tentacular surface to tentacle illustrated in Fig. 5. Fig. 7. Basal armature, external surface.

much smaller hooks 4 (4') compared to the neighbouring hooks 3 (3') and 5 (5') and also possess only slight space between hooks 1 and 1'. These features differ from the generic diagnosis provided by Beveridge et al. (2004). The diagnosis provided by these authors (Beveridge et al. 2004), however, is not applicable for all species within Prochristianella, as discussed in detail by Schaeffner and Beveridge (2012).

Prochristianella mattisi is characterised by a relatively large scolex lacking enlarged microtriches covering its surface and segments with more than 50 testes, a basal tentacular armature with a basal swelling with similarly sized hooks and absence of enlarged billhooks, and eight hooks per principle row in the metabasal armature. Because of these morphological characteristics, we consider the present specimens to represent a new species, which can be readily distinguished from all other congeners. Unfortunately, only very few, slightly convoluted mature segments were present and detailed features of the cirrus sac cannot be provided at present.

The new species is described from a single locality in Tasmania and was obtained from two specimens of the wedgenose skate, Dipturus whitleyi. Only two other trypanorhynch species are reported from this host, namely Dollfusiella martini (Beveridge) Beveridge et Jones and P. clarkeae - Beveridge (1990). The geographic distribution of $D$. whitleyi is limited to the eastern Indian Ocean, where it occurs exclusively in southern Australian waters. This relatively narrow distribution of the host and the occurrence of this parasite in a single host species lead to the assumption that $P$. mattisi might be a parasite endemic to the southern ocean with a high host specificity. 


\section{Key to the species of Prochristianella}

This key is simplified, with only the most easily observed characteristics utilised. To confirm identifications, original species descriptions and/or re-descriptions should be consulted.

1 Scolex covered with enlarged, microscopically visible microtriches ............................................................ 2

- Scolex lacking enlarged microtriches ......................... 6

2 Cestode longer than $4 \mathrm{~mm}$........................................ 3

- Cestode shorter than $4 \mathrm{~mm}$......................................... 4

3 Short, ovoid bulbs; bulb ratio $1.0: 5.4 ; 43-57$ testes .

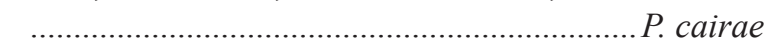

- Long, slender bulbs; bulb ratio $1.0: 10.6 ; 28-35$ testes P. thalassia

4 Scolex larger than $1 \mathrm{~mm}$; more than 40 testes ......... 5

- Scolex smaller than $1 \mathrm{~mm} ; 30-37$ testes P. multidum

5 Metabasal tentacular armature with greatly enlarged, uncinate hook 1 and much smaller, falcate hook 1' ...

P. hispida

- Metabasal armature with uncinate hooks 1 (1'); hooks 1 only slightly larger than hooks 1 ' ......... P. clarkeae

6 Segments with fewer than 25 testes ......................... 7

- Segments with more than 30 testes ........................... 8

7 Scolex 530-680 $\mu \mathrm{m}$ long; bulbs 180-350 $\mu \mathrm{m}$ long and 30 to $50 \mu \mathrm{m}$ wide; metabasal tentacular armature with 9 hooks per principle row; hooks 1 (1') very small; enlarged hooks at base of tentacle absent

P. minima

- Scolex 692-1200 $\mu \mathrm{m}$ long; bulbs 325-470 $\mu \mathrm{m}$ long and $54-75 \mu \mathrm{m}$ wide; metabasal tentacular armature with 13-15 hooks per principle row; hooks 1 (1') large and robust; enlarged hooks at base of tentacle present

P. omunae

8 Pre- and postporal testes in equal numbers; genital pores median; gland-cells within bulbs absent

P. jensenae

- Greater number of preporal testes than postporal ones; genital pores in posterior half of segment; gland-cells within bulbs present 9

9 Scolex longer than $3 \mathrm{~mm}$; bulbs longer than $1 \mathrm{~mm}$.... . P. glabra

- Scolex shorter than $2.2 \mathrm{~mm}$; bulbs shorter than $0.85 \mathrm{~mm}$

10 Hooks 1 (1') represent largest hooks within principle row in metabasal armature ............... P. heteracantha

- Hooks 1 (1') smaller than hooks 2 (2') .. 11

11 Gradation in hook sizes (increase and subsequent decrease) along principle row interrupted by smaller hook
- Gradual increase and decrease of hook sizes along principle row ....................................................... 16

12 Bulbs shorter than $420 \mu \mathrm{m}$; fewer than 50 testes per segment ...................................................... 13

- Bulbs longer than $450 \mu \mathrm{m}$; more than 50 testes per segment

13 Scolex 960-1250 $\mu \mathrm{m}$ long; bulbs 330-420 $\mu \mathrm{m}$ long; hooks 1 (1') and 2 (2') present in proximal 4-6 rows of metabasal armature, absent anteriorly

.. P. mooreae

- Scolex 640-1050 $\mu \mathrm{m}$ long; bulbs 250-340 $\mu \mathrm{m}$ long; hooks 1 (1') and 2 (2') persist along the tentacle .......

P. aciculata

14 Bulbs longer than $600 \mu \mathrm{m}$; retractor muscle within bulb very wide; 8 hooks per principle row in metabasal armature

P. mattisi

- Bulbs shorter than $570 \mu \mathrm{m}$; retractor muscle not widened; 10 hooks per principle row 15

15 Gland-cells inconspicuous; enlarged hooks at base of tentacle present; 2 additional hooks posterior to hooks 1 (1') present in most proximal part of metabasal armature P. scholzi

- Gland-cells large; enlarged hooks at base of tentacle absent; additional hooks posterior to hooks 1 (1') absent in metabasal armature

P. kostadinovae

16 Additional, small hooks at commencement of principle rows in transition from basal to metabasal regions present 17

- Additional hooks at commencement of principle rows absent 18

17 Total length $6.4-12.8 \mathrm{~mm}$; bulbs $360-480 \mu \mathrm{m}$ long and 60-90 $\mu \mathrm{m}$ wide; segments with $34-65$ testes ....... P. papillifer

- Total length 3.5-4.2 mm; bulbs 360-370 $\mu \mathrm{m}$ long and 50-60 $\mu \mathrm{m}$ wide; segments with about 63 testes

P. tumidula

18 Several, greatly enlarged, characteristic billhooks on basal swelling; 3 greatly enlarged, falcate hooks at base of tentacle ................................. P. odonoghuei - Greatly enlarged billhooks absent on basal swelling; basal hooks not or only slightly enlarged 19

19 Principle rows in metabasal armature with dissimilar number of hooks (i.e. 8 and 10 hooks); principle rows begin on antibothrial surface and terminate on bothrial surface P. butlerae Principle rows in metabasal armature with equal number of hooks; principle rows begin on bothrial surface and terminate on antibothrial surface

P. fragilis 


\section{DISCUSSION}

The current description of a new species of Prochristianella brings the total number of species within the genus to 20. It also allows a more precise definition of the genus based on morphological grounds. However, some species show morphological inconsistencies with the most recent generic diagnosis by Beveridge et al. (2004). Five species (i.e. P. aciculata, P. kostadinovae, P. mattisi, $P$. mooreae and P. scholzi), for instance, show a gradation in hook sizes along the principle rows (i.e. hook sizes first increasing and then decreasing), which is interrupted by a much smaller hook in-between two larger ones. In $P$. heteracantha, hooks 1 and 1' are much larger than the succeeding hooks of the principle row, which, by definition, would make its placement within Prochristianella dubious. One species, $P$. jensenae, however, represents the most remarkable species currently placed in the genus. It lacks both gland-cells within the muscular bulbs and a basal swelling on the tentacular armature. Although Schaeffner and Beveridge (2012) supported its placement within Prochristianella, they admitted that subsequent molecular analyses might reveal an independent status of this species, which could then lead to the erection of a separate genus (see Schaeffner and Beveridge 2012). All species of Prochristianella, which are currently considered valid, have been included in a key (see above).

In recent molecular phylogenetic studies performed by Palm et al. (2009) and Olson et al. (2010), species of Prochristianella formed two distinct clusters, rendering the genus polyphyletic (see Schaeffner and Beveridge 2012). The first clade included species with solid hooks and microscopically visible, enlarged microtriches cover- ing the scolex peduncle (e.g. P. clarkeae and P. hispida), whereas the second cluster grouped species with hollow hooks and lacking enlarged microtriches on their scoleces (e.g. P. aciculata and P. scholzi) (see Schaeffner and Beveridge 2012). The addition of species of Prochristianella with solid or hollow hooks and with or without enlarged microtriches in future phylogenetic studies could reveal the importance of these morphological characters. This might subsequently split the genus into Prochristianella (i.e. with hollow hooks and absence of enlarged microtriches) and a separate, closely related genus (i.e. for taxa with solid hooks and presence of enlarged microtriches). However, until further studies reveal a separation of species based on these features, we tentatively retain all species in the same genus.

Based on some morphological characteristics presented by several species of Prochristianella, we emphasise the importance of ethanol-fixed material for molecular studies. Further phylogenetic studies might provide additional information on the interrelationships of species. Furthermore, new morphological characters are needed to confirm the existence and membership of monophyletic groups within the genus. Although an updated generic diagnosis might be necessary, we are unable to provide that information at present.

Acknowledgments. We are very grateful to Bruce Robertson for the collection of material from Tasmania. This project was funded in parts by the National Science Foundation (NSF) (PBI award No. 0818696 awarded to Janine N. Caira and No. 0818823 awarded to Kirsten Jensen), and collections by the Australian Biological Resources Study.

\section{REFERENCES}

Beveridge I. 1990: Taxonomic revision of Australian Eutetrarhynchidae Guiart (Cestoda: Trypanorhyncha). Invertebr. Taxon. 4: 785-845.

Beveridge I., Justine, J.-L. 2010: Two new species of Prochristianella Dollfus, 1946 (Platyhelminthes, Cestoda) from the blue-spotted stingray, Neotrygon kuhlii (Müller \& Henle, 1841) off New Caledonia. Zoosystema 32: 643-652.

Beveridge I., Neifar L., Euzet L. 2004: Eutetrarhynchid cestodes from Atlantic and Mediterranean elasmobranch fishes, with the description of two new species of Dollfusiella Campbell \& Beveridge, 1994 and redescriptions of Prochristianella papillifer (Poyarkoff, 1909) Dollfus, 1957 and Parachristianella trygonis Dollfus, 1946. Syst. Parasitol. 59: 81-102.

Caira, J.N., Jensen, K., Healy, C.J. 1999: On the phylogenetic relationships among tetraphyllidean, lecanicephalidean and diphyllidean tapeworm genera. Syst. Parasitol. 42: 77-151.

Campbell R.A., Beveridge I. 1994: Order Trypanorhyncha Diesing, 1863. In: L.F. Khalil, A. Jones, R.A. Bray (Eds.), Keys to the Cestode Parasites of Vertebrates. CABI, Wallingford, pp. 51-148.
Chervy L. 2009: Unified terminology for cestode microtriches: a proposal from the International Workshops on Cestode Systematics in 2002-2008. Folia Parasitol. 56: 199-230.

Dollfus R.P. 1942: Études critiques sur les Tétrarhynques du Muséum de Paris. Arch. Mus. Natl. Hist. Nat. (Paris) 19: 1-466.

Dollfus R.P. 1946: Notes diverses sur les tétrarhynques. Mem. Mus. Natl. Hist. Nat. (Paris) 22: 179-220.

Hyman, L.H. 1951: The Invertebrates: Platyhelminthes and Rhynocoela. The Acoelomate Bilateria. Vol. 2. McGraw-Hill, New York, 550 pp.

Friggens M.M., Duszynski D.W. 2005: Four new cestode species from the spiral intestine of the round stingray, Urobatis halleri, in the northern Gulf of California, Mexico. Comp. Parasitol. 72: $136-149$.

Jones M.K., Beveridge I., Campbell R.A., Palm H.W. 2004: Terminology of the sucker-like organs of the scolex of trypanorhynch cestodes. Syst. Parasitol. 59: 121-126.

Naylor G.J.P., Caira J.N., Jensen K., Rosana K.A.M., Straube N., LAKNER C. 2012: Elasmobranch phylogeny: a mitochondrial estimate based on 595 species. In: J.C. Carrier, J.A. Mu- 
sak and M.R. Heithaus (Eds.), The Biology of Sharks and Their Relatives. CRC Press, Boca Raton, Florida, pp. 31-56.

Olson P.D., Caira J.N., Jensen K., Palm H.W., Overstreet R.M., Beveridge I. 2010: Evolution of the trypanorhynch tapeworms: parasite phylogeny supports independent lineages of sharks and rays. Int. J. Parasitol. 40: 223-242.

PaLm H.W. 2004: The Trypanorhyncha Diesing, 1863. PKSPL-IPB Press, Bogor, 710 pp.

Palm H.W., Waeschenbach A., Olson P.D., Littlewood D.T.J. 2009: Molecular phylogeny and evolution of the Trypanorhyn-

Received 18 October 2012 cha Diesing, 1863 (Platyhelminthes: Cestoda). Mol. Phylogenet. Evol. 52: 351-367.

Schaeffner B.C., Beveridge I. 2012: Prochristianella Dollfus, 1946 (Trypanorhyncha: Eutetrarhynchidae) from elasmobranchs off Borneo and Australia, including new records and the description of four new species. Zootaxa 3504: 1-25.

Schaeffner B.C., Gasser R.B., Beveridge I. 2011: Ancipirhynchus afossalis n. g., n. sp. (Trypanorhyncha: Otobothriidae), from two species of sharks in Indonesian and Malaysian Borneo. Syst. Parasitol. 79: 83-107.

Accepted 14 February 2013 